\title{
O impacto dos desreguladores endócrinos ambientais sobre a saúde pública
}

Nos últimos anos, provavelmente nenhuma outra questão de toxicologia ambiental tenha chamado mais atenção da comunidade científica e das autoridades regulatórias do que a desregulação endócrina. Os compostos com atividade endócrina (CAEs), desreguladores endócrinos, eco-hormônios, substâncias com atividade hormonal ou xerormônios foram definidos no sentido mais amplo como "qualquer substância exógena que interfere com a síntese, armazenamento/liberação, transporte, metabolismo, atividade conjugadora ou eliminação de hormônios naturais na corrente sangüinea que são responsáveis pela regulação da homeostase e pelo desenvolvimento" ou "qualquer substância exógena que causa efeitos adversos à saúde, secundários a alterações da função endócrina em organismos intactos, ou na sua prole". Sabe-se há muito tempo, que diversos compostos xenobióticos quando ministrados em doses suficientes (geralmente bastante elevadas), podem interagir com uma série de sistemas endócrinos, inclusive com o eixo hipotalâmico-hipofisário, função tireóide e órgãos sexuais. Por exemplo, em 1950, Burlington \& Lindeman, já relatavam que doses elevadas de DDT causavam atrofia testicular e portanto, produziam a feminização dos caracteres sexuais masculinos secundários de galos white leghorn. Nos anos 60, foi observado que a exposição intra-uterina ao potente estrógeno sintético dietil-estilbestrol (DES), mostrava associação causal com o desenvolvimento de adenocarcinoma vaginal durante a adolescência ou no início da idade adulta. Também nos anos 60, Rachel Carlson publicou seu famoso livro Silent Spring (Primavera Silenciosa), chamando atenção para a insuficiência reprodutiva em aves, provocada pela bioacumulação de pesticidas organoclorados persistentes.

Apesar desta e de outras advertências, foi apenas nos anos 90, que a preocupação quanto às conseqüências da exposição de seres humanos e animais selvagens aos desreguladores endócrinos ambientais tornou-se questão de intenso debate. Atualmente, existem evidências convincentes de que a exposição de animais selvagens a níveis elevados de CAEs, pode resultar em deficiências reprodutivas e do desenvolvimento, tais como malformações genitais, comportamento de acasalamento aberrante e insuficiência reprodutiva, entre outras. No entanto, ainda não há consenso sobre os efeitos adversos dos CAEs nos níveis atuais de exposição ambiental.

Os hormônios são potentes moduladores de diversas funções bioquímicas e fisiológicas, e há evidências de que diversas condições patológicas (tais como o câncer de mama, testículo e próstata, além da disfunção reprodutiva) sejam afetadas por influências hormonais. Portanto, é teoricamente plausível a hipótese de que a exposição aos CAEs seja capaz de induzir efeitos adversos para a saúde. Entretanto, a maioria dos CAEs investigada até agora, mostrou um mimetismo hormonal bastante débil, várias ordens de grandeza menor do que os efeitos dos hormônios fisiológicos em diversos ensaios in vitro e in vivo. Por exemplo, o suposto xeno-estrógeno pp-DDE parece ser pelo menos $10^{7}$ menos potente do que o $\beta$-estradiol no ensaio in vitro de estrogenicidade com levedura. Se esta for a regra entre os CAEs ambientais, então seu impacto sobre a saúde humana dependeria fundamentalmente da possibilidade de relações de dose-efeito não-monotônicas, além da importância da exposição a doses baixas e do tipo de interação entre diferentes CAEs.

Apesar das atuais incertezas e dos problemas acima mencionados com a reproduzibilidade dos dados experimentais, a hipótese de que os compostos químicos ambientais possam induzir efeitos adversos sobre a saúde humana através da mediação endócrina, permanece como hipótese plausível que requer investigação em maior profundidade. Este número especial dos Cadernos de Saúde Pública, com artigos de pesquisadores da América Latina, Europa, América do Norte e Japão, pretende contribuir para a discussão desta questão central: qual é o impacto provocado sobre a saúde pública pelos níveis atuais de exposição aos desreguladores endócrinos ambientais?

Sergio Koifman

Escola Nacional de Saúde Pública, Fundação Oswaldo Cruz
Francisco José Roma Paumgartten

Escola Nacional de Saúde Pública, Fundação Oswaldo Cruz 


\section{Impact of environmental endocrine-active substances on Public Health}

In recent years, probably no other topic in environmental toxicology has received more attention from the scientific community and regulatory authorities worldwide than the issue of endocrine disruption. Endocrine-active compounds (EACs), endocrine disruptors, ecohormones, hormonally-active substances, or xerohormones have been broadly defined as "any exogenous substance that interferes with the synthesis, storage/release, transport, metabolism, binding action, or elimination of blood-carrier natural hormones that are responsible for the regulation of homeostasis and development" or "any exogenous substance that causes adverse health effects secondary to endocrine function alterations in intact organisms or their offspring". It has long been known that a number of xenobiotic compounds when given at sufficient (mostly rather high) doses may interact with a variety of endocrine systems, including the hypothalamic-hypophyseal axis, thyroid gland function, and sex organs. For example, as early as 1950 Burlington \& Lindeman reported that high doses of DDT caused testicular atrophy, thereby producing feminization of male secondary sex characters in White Leghorn cockerels. In the 1960s it was observed that prenatal exposure to diethylstilbestrol (DES), a potent synthetic estrogen, was causally associated with the development of vaginal adenocarcinoma during adolescence or early adulthood. Also in the 1960s, Rachel Carlson published her remarkable book Silent Spring, calling attention to the reproductive failure of birds caused by bioaccumulation of persistent organochlorine pesticides.

Despite these and other early warnings, it was not until the 1990s that concern over the adverse consequences of human and wildlife exposure to environmental endocrine-active compounds became a matter of intense debate. There is now convincing evidence that wildlife exposure to high levels of EACs may result in reproductive and developmental deficits such as malformed genitalia, aberrant mating behavior, and reproductive failure, among others. Nevertheless, whether EACs have adverse consequences at current environmental exposure levels is still a controversial matter.

Since hormones are potent modulators of biochemical and physiological functions and there is evidence that a number of pathological conditions (such as breast, testicular, and prostate cancer and reproductive dysfunction) are affected by hormonal influences, the hypothesis that exposure to EACs is capable of inducing adverse health effects is, in principle, plausible. However, most EACs investigated so far have proven to have rather weak hormone-like effects, orders of magnitude lower than the effects of the physiological hormones, in different in vitro and in vivo assays. For example, the putative xenoestrogen pp-DDE appears to be at least $10^{7}$ less potent than $\beta$-estradiol in the in vitro yeast estrogenicity assay. If this is the rule among environmental EACs, then their impact on human health would critically depend on the possibility of non-monotonic dose-effect relationships, besides relevance of exposures to low doses, as well as on the type of interaction between different EACs.

Despite today's uncertainties and the foregoing problems of reproducibility of experimental data, the hypothesis that environmental chemicals could induce endocrine-mediated adverse effects on human health remains a plausible hypothesis that deserves to be investigated in depth. This special issue of Cadernos de Saúde Pública/Reports in Public Health, with contributions by researchers from Latin America, Europe, North America, and Japan, is intended to add to the discussion of this central question: what is the impact of current levels of exposure to environmental EACs on public health?

Sergio Koifman

Escola Nacional de Saúde Pública, Fundação Oswaldo Cruz
Francisco José Roma Paumgartten

Escola Nacional de Saúde Pública, Fundação Oswaldo Cruz 